\title{
УПРАВАІННЯ ВІДХОДАМИ
}

\author{
УДК 504.064.45 \\ DOI https://doi.org/10.32846/2306-9716/2020.eco.4-31.35
}

\section{КААСИФІКАЦІЯ СІАЬСЬКОГОСПОДАРСЬКИХ ВІДХОДІВ I BИБIP TEXHОАОГIї ÏХ УТИАIЗАЦIї}

\author{
Горобець О.В. \\ Житомирський національний агроекологічний університет \\ Старий бульвар, 7, 10008, м. Житомир \\ o.vikt.gorobets@gmail.com
}

\begin{abstract}
Проаналізовано вітчизняний та європейський підходи до класифікації сільськогосподарських відходів. Встановлено, що класифікація відходів у Державному класифікаторі відходів ДК 005-96 не дозволяє чітко визначити, до якої категорії відходів (безпечних чи небезпечних) належить певний вид відходів, які способи поводження варто застосовувати до кожного 3 них.

Запропоновано поділяти відходи, які утворюються в галузі рослинництва і тваринництва, на дві групи: органічні та неорганічні, які поділяються на безпечні і малонебезпечні відходи (IV класу небезпечності) та на небезпечні відходи (I-III класів небезпечності). Запропонована класифікація відповідає європейському підходу та діючому Державному класифікатору відходів і дозволяє здійснювати вибір відповідних технологій знешкодження конкретних видів відходів.

Проаналізовано сучасні методи поводження з сільськогосподарськими відходами відповідно до запропонованої класифікації відходів. Встановлено, що найкращим способом поводження з відходами, які належать до органічних безпечних і малонебезпечних відходів, $€$ їх утилізація за допомогою біологічних технологій, які $є$ найбільш екологічно безпечними.

Розглянуто сутність, переваги і недоліки анаеробного зброджування, аеробного компостування та вермикомпостування. Запропоновано розглядати неорганічні безпечні та малонебезпечні сільськогосподарські відходи в якості потенційних вторинних ресурсів, тому необхідно здійснювати їх роздільне збирання і первинне сортування з подальшим спрямуванням на

Визначено, що основним методом поводження з відходами, які належать до небезпечних, є видалення, хоча у певних випадках органічні небезпечні відходи можуть бути утилізовані. Наведено дані щодо можливості утилізації зазначених видів сільськогосподарських відходів. Ключові слова: сільськогосподарські відходи, класифікація відходів, безпечні і небезпечні відходи, утилізація відходів.
\end{abstract} утилізацію.

Classification of agricultural waste and the choice of the technology for their recycling. Horobets $O$.

Domestic and European approaches to the classification of agricultural waste are analyzed. It is established that the classification of waste in the State Waste Classifier DK 005-96 does not allow to clearly determine to which category of waste (safe or hazardous) a certain type of waste belongs to and, accordingly, what methods of treatment should be applied to each of them.

It is proposed to divide the waste generated in the field of crop and livestock production into two groups: organic and inorganic, which, in turn, are divided into safe waste, low-hazardous waste (hazard class IV) and hazardous waste (hazard class I-III). The proposed classification corresponds to the European approach and to current State Waste Classifier enabling the selection of appropriate technologies for disposal of specific types of waste.

Modern methods of agricultural waste management in accordance with the proposed classification of waste are analyzed. It has been established that the best way to manage waste belonging to organic safe and low-hazardous waste is to recycle it using biological technologies that are the most environmentally friendly. The essence, advantages and disadvantages of anaerobic fermentation, aerobic composting and vermicomposting are considered.

It is proposed to consider inorganic safe and low-hazardous agricultural waste as potential raw material, so it is necessary to carry out their separate collection and primary sorting with subsequent recycling. It has been determined that the main method of handling hazardous waste is disposal, although in some cases the organic hazardous waste can be recycled.

The data on the possibility of utilization of these types of agricultural waste are given. The proposed waste classification can be used by stakeholders and local governments to improve the management of agricultural waste. Key words: agricultural waste, waste classification, safe and hazardous waste, recycling, waste management.

Постановка проблеми. Клімато-географічні умови України, наявність достатніх земельних, водних і трудових ресурсів сприяють розвитку в країні сільськогосподарського виробництва, яке має важливе значення для економіки нашої держави. Так, у 2019 році внесок сільського господарства, лісового та рибного господарства в загальну суму валової доданої вартості становив $10,5 \%$ (у 2010 році ця частка складала $8,4 \%)[1$, с. 8$]$.
Сільськогосподарське виробництво, яке протягом десятиліть здійснюється без урахування негативних наслідків для навколишнього природного середовища, спричиняе появу багатьох екологічних проблем, зокрема забруднення довкілля відходами. Протягом останніх трьох років обсяг сільськогосподарських відходів (тобто таких, що утворюються в процесі сільськогосподарського виробництва) не перевищував 3\% від загальної кількості утворених 
у країні відходів. Незважаючи на це, сільськогосподарські відходи є джерелом забруднення повітря, водних і земельних ресурсів, що призводить до появи економічних збитків і соціальних проблем (погіршення стану здоров'я та якості життя населення).

Актуальність дослідження. Із загального обсягу відходів, які щорічно утворюються в сільському господарстві, утилізується (тобто використовується в якості вторинних матеріальних чи енергетичних ресурсів) менше половини. Інші спалюються або вивозяться на звалища, де продовжують забруднювати довкілля. Натомість сільськогосподарські відходи можна ефективно використовувати в якості добрива, джерела енергії чи вторинної сировини. Саме тому вирішення проблеми поводження 3 сільськогосподарськими відходами є досить актуальним.

Зв'язок авторського доробку з важливими науковими та практичними завданнями. Оскільки в процесі сільськогосподарського виробництва утворюються різні види відходів, кожен із яких потребує свого способу утилізації чи видалення, важливим складником успішного управління відходами $\epsilon$ їх класифікація. Запропонована в статті класифікація сільськогосподарських відходів дозволить спростити вибір оптимальних способів поводження 3 кожним видом відходів, що сприятиме удосконаленню управління такими відходами і зменшенню їх шкоди для довкілля і здоров'я людей.

Аналіз останніх досліджень і публікацій. Вирішенню проблеми ефективного використання та утилізації сільськогосподарських відходів присвятили свої дослідження багато вітчизняних і зарубіжних науковців: Г. Гелетуха, І. Демчак, А. Долінський, Т. Желєзна, М. Жовнір, Ю. Матвєєв, Ю. Кернасюк, М. Кобець, В. Лісничий, В. Сіденко, С.Y. Chang, C.S. Chen, E. Davies, G. Gautam, Y. Liu, P. Malatji, J.-L. Shie та інші. Управлінські аспекти використання сільськогосподарських відходів вивчають І.В. Замула, Г.М. Калетнік, О.П. Скорук, Д.М. Токарчук, S.К. Brar, F. Gassara, F. Pelletier, Y. Hara, T. Furutani, A. Murakami.

Виділення не вирішених раніше частин загальної проблеми, котрим присвячусться означена стаття. Незважаючи на наявність певних наукових розробок, а також чинного Державного класифікатора відходів, можна зазначити, що класифікація сільськогосподарських відходів в Україні ще не повністю узгоджена і потребує додаткових досліджень.

Новизна. Удосконалено класифікацію сільськогосподарських відходів, яка дозволяє здійснювати вибір відповідних технологій утилізації чи видалення конкретних видів відходів. Здійснено огляд відповідних технологій згідно із запропонованою класифікацією сільськогосподарських відходів.

Виклад основного матеріалу. У науковій літературі існують різні класифікації відходів. В.М. Радовенчик і М.Д. Гомеля пропонують поділяти сільськогосподарські відходи на відходи природного походження (галузей рослинництва і тваринництва) та штучного походження (пестициди і агрохімікати) [2, с. 269]. Проте в процесі вирощування продукції рослинництва і тваринництва використовується також багато інших матеріалів, частина яких перетворюється на відходи (наприклад, поліетиленова плівка, що використовується для накриття парників), які не враховуються запропонованою класифікацією.

За ступенем небезпечності сільськогосподарські відходи відносять до чотирьох класів небезпеки: I клас - надзвичайно небезпечні; II клас - високо небезпечні; III клас - помірно небезпечні; IV клас мало небезпечні.

Свропейський підхід до класифікації відходів також передбачає їх розподіл на безпечні і небезпечні згідно 3 джерелом походження та складом відходу. Класифікація відходів базується на Європейському переліку відходів (the European List of Waste) [3] та Додатку III до Директиви 2008/98/СС, які дозволяють однозначно ідентифікувати будь-який вид відходів і віднести його до класу безпечних чи небезпечних. Зокрема, у списку відходів небезпечні відходи позначені зірочкою.

В Україні також розроблено Державний Класифікатор відходів ДК 005-96 (ДК), згідно 3 яким відходи виробництва продукції сільського господарства та мисливства включено до групи 01, до якої належать такі класифікаційні угруповання [4]: відходи виробництва зернових культур, продукції овочівництва та садівництва (011); відходи вирощування тварин і виробництва продукції тваринництва (012); відходи виробництва продукції змішаного господарювання (013); відходи від надання послуг у рослинництві та тваринництві (014); відходи мисливства, ловіння пасткою, розведення дичини (015); послуги спеціалізовані щодо поводження 3 відходами виробництва продукції сільського господарства та мисливства, які надаються за місцем утворення відходів (0159). В основу класифікації відходів у ДК покладено стадію виробничого процесу, на якій вони утворилися. Тому сільськогосподарські відходи поділяють на відходи вхідних компонентів, виробничо-технологічні відходи та відходи кінцевої продукції [4].

Отже, у ДК кожному виду відходів присвоєно відповідний код залежно від походження відходу. Як зазначають вітчизняні науковці, це спрощує пошук і дозволяє вирішувати проблему кодифікації відходів [5]. Однак така класифікація не дозволяє чітко визначити, до якої категорії відходів (безпечних чи небезпечних) належить певний вид відходів, які способи поводження варто застосовувати до кожного 3 них.

Згідно з європейською ієрархією методів поводження 3 відходами, а також новою державною політикою України у сфері управління відходами кращими способами поводження з відходами, появи яких не вдалося уникнути, $є$ їх утилізація. Саме тому пропонується в основу класифікації сільськогоспо- 
дарських відходів покласти можливість їх утилізації, здійснення якої залежить і від класу небезпечності відходів. Відходи, що утворюються в галузі рослинництва і тваринництва, пропонується поділяти на дві групи: органічні та неорганічні, які поділяються на безпечні і малонебезпечні відходи (IV класу небезпечності) та на небезпечні відходи (I-III класів небезпечності). Запропонована класифікація наведена у вигляді табл. 1.

До кожного із наведених у табл. 1 видів відходів необхідно застосовувати відповідні методи поводження. Так, найкращим способом поводження з відходами, які належать до групи 1.1. і 1.2., $є$ їх утилізація. До відходів, які належать до груп 2.1. і 2.2., найбільш доцільно застосовувати видалення.

Розглянемо зазначені технології більш детально. Оскільки всі відходи, що належать до групи 1.1,
$€$ органічними, вони здатні до біологічного розкладання, до них можна застосовувати біологічні методи утилізації, які є найбільш екологічно безпечними. До таких методів належить аеробне та анаеробне компостування (зброджування) та вермикомпостування.

Як зазначають вітчизняні і зарубіжні науковці, одним із найбільш поширених способів переробки органічних сільськогосподарських відходів, особливо відходів тваринництва, $\epsilon$ ї анаеробне зброджування. Цей спосіб дозволяє знешкоджувати відходи і отримувати при цьому біогаз і високоякісні органічні добрива. В якості основної сировини для анаеробного зброджування в реакторі найчастіше використовують гній ВРХ, свинячий гній і пташиний послід (здебільшого використовують суміш із 2-10 видів субстратів).

Класифікація сільськогосподарських відходів

Таблиця 1

\begin{tabular}{|c|c|c|c|c|}
\hline \multirow{3}{*}{$\begin{array}{c}\text { Галузі } \\
\text { сільського } \\
\text { господарства } \\
\text { та код відходів }\end{array}$} & \multicolumn{4}{|c|}{ Сільськогосподарські відходи } \\
\hline & \multicolumn{2}{|c|}{ 1. Органічні } & \multicolumn{2}{|c|}{ 2. Неорганічні } \\
\hline & $\begin{array}{c}\text { 1.1. Безпечні } \\
\text { і малонебезпечні } \\
\text { (IV клас) }\end{array}$ & $\begin{array}{l}\text { 1.2. Небезпечні (I-III } \\
\text { класи) }\end{array}$ & $\begin{array}{l}\text { 2.1. Безпечні i } \\
\text { малонебезпечні } \\
\text { (IV клас) }\end{array}$ & $\begin{array}{l}\text { 2.2. Небезпечні } \\
\text { (I-III класи) }\end{array}$ \\
\hline Рослинництво & $\begin{array}{l}\text { 1) насіння та саджанці } \\
\text { зіпсовані; } \\
\text { 2) відходи тканин рос- } \\
\text { линного походження; } \\
\text { 3) солома, стебла, } \\
\text { качани кукурудзи; } \\
\text { 4) некондиційна } \\
\text { продукція }\end{array}$ & $\begin{array}{l}\text { 1) продукція, забруд- } \\
\text { нена радіонуклідами; } \\
\text { 2) продукція, забруд- } \\
\text { нена шкідливими } \\
\text { речовинами }\end{array}$ & $\begin{array}{c}\text { відходи матеріа- } \\
\text { лів (поліетилен, } \\
\text { картон, скло, } \\
\text { деревина), } \\
\text { зіпсовані, забруд- } \\
\text { нені або не } \\
\text { ідентифіковані }\end{array}$ & $\begin{array}{l}\text { засоби хімічного } \\
\text { оброблення } \\
\text { насіння і захи- } \\
\text { сту рослин та } \\
\text { добрива міне- } \\
\text { ральні зіпсовані, } \\
\text { забруднені, не } \\
\text { ідентифіковані }\end{array}$ \\
\hline $\begin{array}{l}\text { Код відходів } \\
\text { згідно } \\
\text { з ДК 005-96 }\end{array}$ & $\begin{array}{l}\text { 0111.1.1; 0112.1.1; } \\
0113.1 .1 ; 0111.2 .6 \\
0111.2 .9 ; 0112.2 .9 \\
0113.2 .9 ; 0111.3 .1 \\
0112.3 .1 ; 0113.3 .1\end{array}$ & $\begin{array}{l}0111.3 .2 \\
0112.3 .2 \\
0113.3 .2\end{array}$ & $\begin{array}{l}0112.1 .2 \\
0113.1 .2\end{array}$ & 0111.1 .2 \\
\hline Тваринництво & $\begin{array}{l}\text { 1) фураж, корми для } \\
\text { відгодівлі свійської } \\
\text { птиці, підкормка для } \\
\text { бджіл, корми для шов- } \\
\text { ковичного шовкопряда, } \\
\text { кормові добавки зіпсо- } \\
\text { вані, забруднені або не } \\
\text { ідентифіковані; } \\
\text { 2) відходи тканин тва- } \\
\text { ринного походження, } \\
\text { екскременти, сечовина } \\
\text { та гній від худоби, } \\
\text { послід пташиний; } \\
\text { 3) продукція бракована }\end{array}$ & $\begin{array}{l}\text { 1) продукція від ВРХ, } \\
\text { овець, кіз, коней, } \\
\text { свійської птиці, інших } \\
\text { тварин некондиційна, } \\
\text { забруднена радіонуклі- } \\
\text { дами та/або шкідли- } \\
\text { вими речовинами; } \\
\text { 2) тварини, уражені } \\
\text { небезпечними інфек- } \\
\text { ційними захворюван- } \\
\text { нями або забруднені } \\
\text { радіонукідами та/ } \\
\text { або шкідливими } \\
\text { речовинами }\end{array}$ & $\begin{array}{l}\text { 1) матеріали для } \\
\text { виготовлення } \\
\text { засобів та облад- } \\
\text { нання для утри- } \\
\text { мання тварин } \\
\text { (вуликів, стелажів, } \\
\text { кліток, вольєрів } \\
\text { тощо) зіпсовані, } \\
\text { забруднені або не } \\
\text { ідентифіковані, їх } \\
\text { залишки, які не } \\
\text { використовуються } \\
\text { за призначенням }\end{array}$ & $\begin{array}{l}\text { 1) засоби утри- } \\
\text { мання тварин, } \\
\text { уражених небез- } \\
\text { печними інфек- } \\
\text { ційними захво- } \\
\text { рюваннями, } \\
\text { забруднені раді- } \\
\text { онуклідами та/ } \\
\text { або шкідливими } \\
\text { (небезпечними) } \\
\text { речовинами; }\end{array}$ \\
\hline $\begin{array}{l}\text { Код відходів } \\
\text { згідно з ДК } \\
005-96\end{array}$ & $\begin{array}{c}0121.1 .1 ; 0122.1 ; 0123.1 ; \\
0124.1 ; 0125.1 ; 0130.1 ; \\
0121.2 .6 ; 0122.2 ; 0123.2 ; \\
0124.2 .6 ; 0125.2 .6 \\
0125.2 .9 ; 0130.2 ; \\
0121.3 .1 ; 0122.3 .1 \\
0123.3 .1 .01 ; 0124.3 .1 \\
0125.3 .1 ; 0130.3\end{array}$ & $\begin{array}{l}\text { 0121.3.2; } \\
0122.3 .2 \\
0123.3 .2 \\
0124.3 .2 \\
0125.3 .2 .01 \\
0125.3 .2 .03 \\
0125.3 .2 .04\end{array}$ & 0125.1 .2 & 0125.3.2.02 \\
\hline
\end{tabular}

Джерело: розроблено автором на основі [4] 
Для ефективного анаеробного зброджування тваринних екскрементів додають інші органічні відходи (наприклад, рослинні). Це досить складний процес, для управління яким необхідно контролювати певні параметри (температуру, кислотність, наявність токсичних речовин), а також забезпечити безперервне та рівномірне протягом доби завантаження-розвантаження органічної речовини; оптимальну інтенсивність перемішування сировини в резервуарі; підтримання оптимальної температури зброджування; забезпечення нормальної діяльності метаноутворюючих бактерій.

При виробництві біогазу шляхом анаеробного зброджування органічних відходів кількість виробленої енергії складає 203-2950 МДж/т. При цьому витрати на впровадження такої технології досить високі, внаслідок чого окупність біогазових проектів складає від 6 до 14 років [6, с. 16]. 3 метою скорочення терміну окупності таких проектів до 4-8 років підприємство може купувати електроенергію за звичайним тарифом для промислових підприємств, а електроенергію, вироблену з біогазу, продавати за зеленим тарифом.

Після анаеробного зброджування в органічній суміші майже не залишається яєць гельмінтів, хвороботворних мікроорганізмів і насіння бур'янів, тому iii можна використовувати для виготовлення добрив (компосту). Компост знаходить широке застосування в якості добрива в сільському, лісовому, зеленому господарстві; для рекультивації земель; в якості палива (після попередньої сушки до вологості 3-8\% і брикетування).

До недоліків біогазових технологій потрібно віднести великі витрати на обладнання, будівництво інфраструктури для підключення до електромережі, отримання дозволів; значний термін окупності інвестицій; необхідність постійної наявності органічної сировини. Перевагами біогазових технологій $є$ те, що вони дозволяють вирішувати певний спектр проблем: екологічну (повна утилізація органічних відходів рослинництва і тваринництва); енергетичну (отримання та використання біогазу); агрохімічну (отримання якісних органічних добрив і поліпшення родючості грунту); соціальну (покращення умов праці, створення додаткових робочих місць); економічну (зменшення витрат на оплату екологічного податку, отримання прибутку від реалізації добрив) [2, с. 280].

Аеробне компостування відбувається в присутності повітря на відкритих ділянках. Найбільш широко компостування використовується для переробки рослинних відходів, проте для підвищення ефективності компостування додають сухий гній, солому, тирсу. Кінцевим продуктом компостування $є$ компост - органічне добриво.

Останнім часом все більше уваги у світі приділяється розвитку вермикомпостування, або вермикультури. В результаті можна отримати біогумус - високомолекулярні органічні сполуки, що утворюються внаслідок життєдіяльності черв'яків у процесі пере- роблення ними органічних речовин. Біогумус має високий вміст біогенних елементів у легкодоступній формі, є однорідним і розсипчастим. Під впливом черв'яків процес компостування проходить втричі швидше, ніж аеробне компостування [7, с. 221].

Недоліками компостування $є$ досить тривалий термін виготовлення компосту, необхідність і складність дотримання вимог щодо вмісту в компості та на земельних ділянках, де він використовується, забруднюючих речовин, зокрема, важких металів.

Перевагами компостування є зменшення забруднення довкілля відходами; можливість отримання добрив; поліпшення родючості грунту, зниження ймовірності ерозії грунту; зменшення витрат на мінеральні добрива; більш проста і дешева технологія порівняно 3 анаеробним зброджуванням, що дозволяє широко ii застосовувати навіть у невеликих господарствах. Загалом проекти з використання компосту в якості добрива є економічно вигідними i мають короткий термін окупності, насамперед внаслідок економії коштів на закупівлю високовартісних мінеральних добрив і за рахунок покращення складу грунтів, збільшення врожайності продукції рослинництва.

Досить вигідним також є спрямування рослинних відходів на корм для відгодівлі тварин чи використання їх у якості підстилки для тварин. У разі утворення великих обсягів рослинних відходів їх також можна успішно використовувати для виготовлення різноманітної продукції - вірьовок, канатів, текстилю, паперових виробів, оббивних, пакувальних, ізоляційних, будівельних матеріалів.

Було підраховано, що виробництво целюлози, паперу або картону із соломи потребує менше капіталовкладень, ніж організація виробництва целюлози 3 деревини. Як свідчить досвід європейських країн, найбільш економічно вигідним є виробництво целюлози з соломи на підприємстві потужністю 10-20 тис. т на добу. Орієнтовна вартість будівництва підприємства складає 15 млн євро, а термін окупності - 5-7 років [6, с. 20].

Що стосується неорганічних безпечних і малонебезпечних сільськогосподарських відходів, які належать до групи 2.1 (табл. 1), вони також підлягають утилізації, оскільки є потенційною вторинною сировиною. 3 метою уникнення забруднення та псування зазначених відходів необхідно запровадити їх роздільне збирання і первинне сортування. Потрібно облаштувати приміщення або критий майданчик, а також відповідні ємності для розміщення і тимчасового зберігання таких відходів. Частину таких відходів можна утилізувати в самому господарстві, наприклад, деревні відходи. Щодо інших, то бажано укласти договір із підприємством чи організацією, які займаються збиранням та утилізацією відповідного виду відходів.

Відходи, що належать до груп 1.2. і 2.2, є небезпечними 3 точки зору екологічної чи санітарно-епіде- 
міологічної безпеки, саме тому переважним способом поводження з такими відходами є видалення. 3 цією метою зазвичай застосовують термічні методи чи захоронення відходів, які здійснюються спеціалізованими підприємствами у спеціально відведених місцях.

Проте органічні відходи, що входять до групи 1.2., у певних випадках також можуть бути утилізовані, зокрема, за допомогою компостування, що було підтверджено численними дослідженнями. Було доведено, що компостування є ефективним способом утилізації рослин, які містять у своїх тканинах ДДТ [8]. Це знайшло своє відображення i в нормативних документах. Було розроблено «Методику вилучення, утилізації та знищення сільськогосподарської сировини і харчових продуктів, що зазнали впливу пестицидів та агрохімікатів і непридатні до використання», в якій зазначено, що найбільш доцільними та безпечними методами знищення продукції, яка зазнала впливу пестицидів i агрохімікатів, $\epsilon$ спалювання або компостування.
Компостування може також успішно застосовуватися для знешкодження трупів загиблих тварин і птиці, у тому числі уражених інфекційними захворюваннями [9]. Особливо це актуально для невеликих господарств, які мають обмежений доступ до санітарних полігонів чи спеціальних спалювальних установок.

Головні висновки. Таким чином, удосконалена класифікація сільськогосподарських відходів, яка передбачає їх розподіл на органічні та неорганічні, а також на безпечні і небезпечні, дозволяє здійснювати вибір відповідних технологій утилізації чи видалення конкретних видів відходів. Перевагами запропонованої класифікації є відповідність європейському підходу та діючому Класифікатору відходів.

Перспективи використання результатів дослідження. Запропонована класифікація відходів може використовуватися зацікавленими суб'єктами господарювання та органами місцевого самоврядування для удосконалення поводження $з$ сільськогосподарськими відходами.

\section{Література}

1. Соціально-економічний розвиток України за січень-травень 2020 року. URL: http://www.ukrstat.gov.ua (дата звернення: 09.08.2020).

2. Радовенчик В.М., Гомеля М.Д. Тверді відходи: збір, переробка, складування. Київ, 2009. 552 с.

3. 2014/955/EU: Commission Decision of 18 December 2014 amending Decision 2000/532/EC on the list of waste pursuant to Directive 2008/98/EC of the European Parliament and of the Council. URL: https://eur-lex.europa.eu/legal-content/EN/ TXT/?uri=celex:32014D0955 (дата звернення: 09.08.2020).

4. Державний класифікатор України. Класифікатор відходів ДК 005-96. URL: https://zakon.rada.gov.ua/rada/show/ v0089217-96\#Text (дата звернення: 09.08.2020).

5. Жуковський Т.Ф., Ткачова О.В., Пшенічнова О.Л., Карцев В.Г. Впровадження в Україні європейського підходу до класифікації відходів. Технологический аудит и резервы производства. № 4/3(30). 2016. С. 27-32.

6. Обращение с отходами агропромышленного комплекса: возможности для Украины. URL: http://www.uabio.org/img/files/ news/pdf/waste-agro-complex-2013.pdf (дата звернення: 09.08.2020).

7. Агрохімія : підручник / Г.М. Господаренко. Київ, 2013. $406 \mathrm{c}$

8. Слободенюк О.А. Утилізація рослин, забруднених дихлордифенілтрихлорметилметаном. Науковий вісник НЛТУ України. 2012. Вип. 22.11. С. 128-132.

9. Міллер Л., Флорі Г. Утилізація туш у малих і середніх тваринницьких фермах: Практичні рекомендації. Focus On. № 13, 2018. Рим. ФАО. 10 с. 